\title{
Design Codes in England - New Urbanist Inspiration?
}

\author{
Ivor Samuels \\ Architect; Honorary Senior Research Fellow, Birmingham University; \\ Tutor, Oxford University Continuing Education. Visiting Lecturer, CRP, Cal Poly.
}

In this article Ivor Samuels, one of FOCUS's most constant collaborators, discusses the growing use of design codes in England and the influence of New Urbanism. He does so by examining Fairfield Park and Upton, two recent successful development schemes, as well as a design code for the West End, Oxford which he coauthored. He concludes by discussing the feasibility of design codes as well as the qualities they should abide by.

$\mathrm{T}$ he form of cities is governed by the layout of the public spaces, mainly its streets, and also by the form of the buildings that define these places. Height limits, the extent to which plots are built out, and the design of the facades with their openings and entrances all influence the form of the "ordinary" buildings (used in the sense of Habraken's 1998 book The pattern of the ordinary) which make up the greater part of our cites. Together with the plan, these rules or codes influence the actions of those who make towns and the resulting qualities, both good and bad, of those places.

This paper reviews an attempt to make design codes more extensively used in England, then briefly examines two successfully implemented codes for large housing developments which were reviewed by the author for the Commission on Architecture and the Built Environment (CABE). These are followed by an examination of a code prepared by the author for a district of Oxford. The code was prepared in an optimistic development climate but it was adopted immediately before the recession of 2008. The paper concludes by reflecting on the lessons from these experiences and the possibilities of transferring them to other contexts.

\section{The Origins of Design Codes in England}

Control over the built form of cities is an ancient practice and some of our best loved places are the result of the imposition of some degree of control through rules or codes, whether imposed by public agencies or private landowners. In England these include the streets and squares of Georgian London and the circuses and crescents of Bath, although Larkham (2001) has pointed out that the first building regulations of significance in England dated from 1189 when the Mayor of London made provisions dealing with party wall matters, obstruction of views and right to light. It was not until the rebuilding of London in the century after the Great Fire of 1666 that regulations were imposed which determined the appearance of many parts of the city with which we are familiar today. These related to four "rates" or types of house defined according to floor area, minimum height linked to specific street locations. In some

favoured locations private landowners imposed more detailed design controls on the developments which they promoted for their urban landholdings, such as those around Bedford Square in London. These controls had the objective of maintaining the value of these projects against attempts to construct housing of inferior quality in the vicinity. This remains a valid reason today for developers to commission design codes for large residential developments which will take many years to complete.

It was not until the 1960s and 1970s that the current interest was revived in qualitative codes and design guides. This started as a reaction to the problems of monotonous and standardised suburban housing design dominated by standards imposed by highway engineers. It was inspired by the work of Gordon Cullen and the Townscape Movement, and the "Outrage" campaign in the Architectural Review Journal led by lan Nairn. ${ }^{1}$ The Essex Design Guide published in 1973 was the first of a continuing line of attempts to counter these problems through detailed residential design guides. It advocated a careful respect for local design traditions even though its advice often neglected the realities of financial viability. For example, it suggested wide frontage lots which would lead to increased infrastructure costs for developers and thus raise the selling price of houses, possibly beyond the reach of the local market.

\section{The Last Decade}

In 2003 the Deputy Prime Minister (himself a visitor to and admirer of Seaside, a new-urbanist development in Florida) announced, during a conference on Rational Urbanism at the Prince's Foundation, that the Government was undertaking research into the potential for adopting design codes. The lines of contact between the Prince of Wales' Foundation and the U.S. New Urbanists have been very close since the building of a traditional urban extension at Poundbury on land belonging to the Duchy of Cornwall-a royal landholding. Now entering its second decade of development, this model community,

\footnotetext{
${ }^{1}$ See Lorenza Pavezzi's article "lan Nairn, Townscape and the campaign against Subtopia" in FOCUS 10, 2013.
} 
designed by the Neoclassicist Leon Krier, reinforced the linkage between the revived British interest in design codes and the New Urbanism (Duchy of Cornwall). They have in common an attempt to control the form and layout of developments through such elements as building typologies, public space standards, and the application of a limited range of architectural components. Poundbury has generated an extensive literature both in support and against its attempt to impose very strict and detailed controls over all aspects of the development (Figures 1 \& 2).

The results of the government initiative were a series of publications (Commission on Architecture and the Built Environment [CABE] 2003, 2005; Department for Communities and Local Government [DCLG], 2006a, 2006b) which set out the role of design coding and demonstrated how it could be incorporated into the British Planning system which is much less regulatory than that of the United States, leaves much to the discretion of the participants, and, of course, thus opens the door to endless litigious conflicts and work for lawyers. This may be the reason why the documents cited are largely concerned with process at the expense of guidance on the substance of design codes.

Carmona and Dann (2007) found a number of common factors in the codes they examined. These included a return to perimeter block urban forms, a desire to integrate with their surroundings, and often a conservative style exemplified by Seaside in the United States and Poundbury in the United Kingdom. An unfortunate by-product of this return to the traditional forms of residential buildings (at least in this author's opinion) has been the use of exceedingly small windows. Justified by developers as reflecting traditional forms, they happen to be a cheaper way of achieving a satisfactory thermal performance than using larger windows. Developers justify this practice by claiming that their neo-traditional designs sell better.

\section{Fairfield Park and Upton}

These are two implemented residential schemes, both of which used design codes and reveal the extent to which these codes are valuable in maintaining overall quality over an extended time periods with a multiplicity of developers. They can also claim some relative success in retaining a high quality of build out on with number of builders not especially noted for the quality of their developments.

At Fairfield Park, a former mental hospital and its surrounding parks and gardens has been transformed into a housing development of 1,200 houses sited in open country two miles north of Letchworth. Incidentally, this was the first English New Town. The mid-nineteenth-century hospital, a protected building of historic interest, has been transformed into apartments. The eight different house builders followed a design code that has consciously reinterpreted the Victorian style of the hospital. This has been used to justify the code's great control of detail, which includes brick window arches and

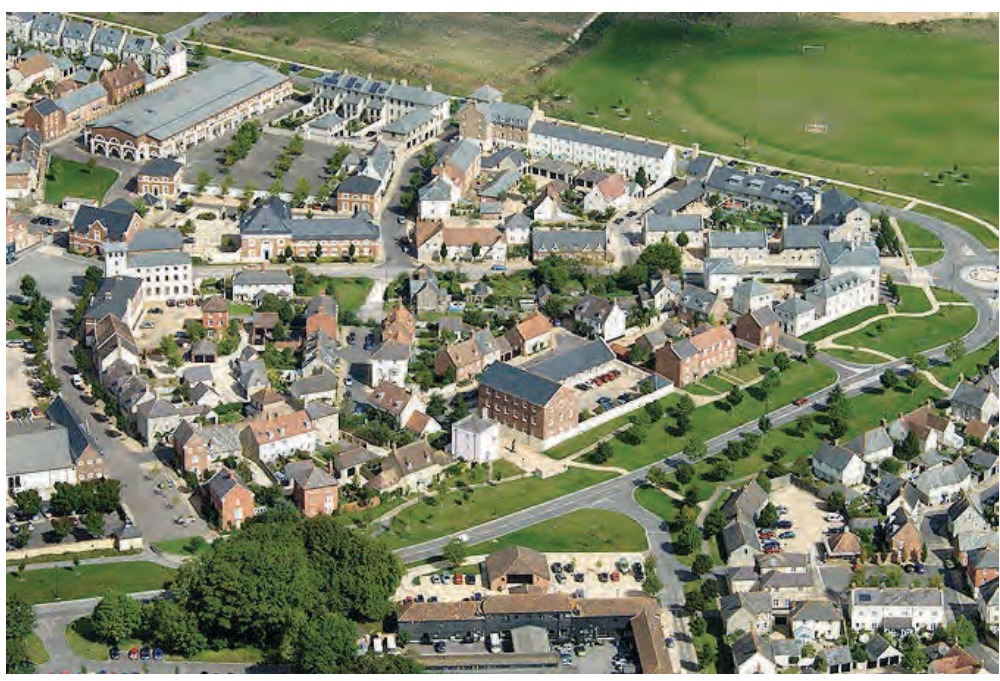

Figure 1: First phase of Poundbury's Master Plan, by Leon Krier. (source: http://www.placemakers.com/2012/08/09)

Figure 2: The Whistling Witch, Poundbury. (photo by Zonda Grattus; http://commons.wikimedia.org/wiki/ File:The_Whistling_Witch,_Poundbury.jpg)

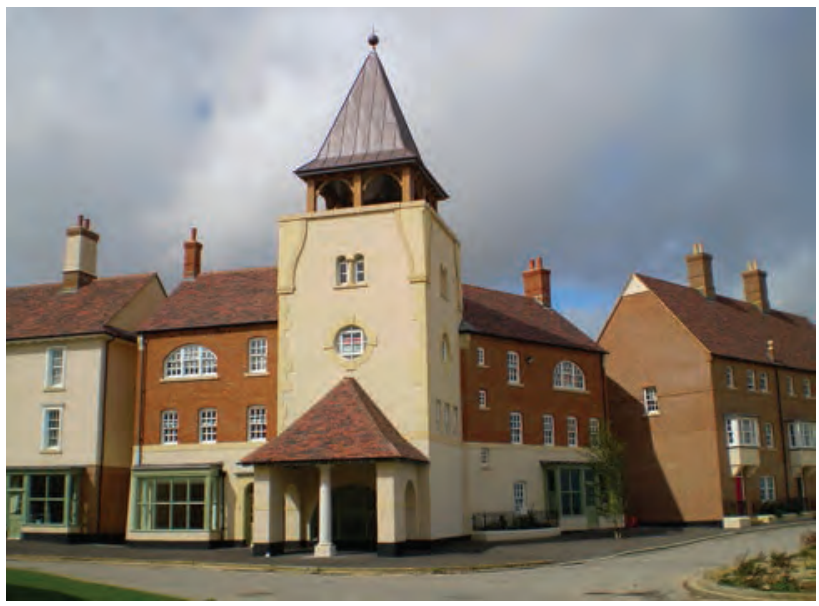

even lays down a range of acceptable colours for painting the front door to the houses. A new primary school, community centre, small supermarket, and playgrounds have been provided within the landscape of mature trees and orchards. One surprising negative aspect of the project is that by virtue of having only one vehicular access from the existing road network and Fairfield Park's distance from neighbouring towns or villages it has become virtually a gated community (CABE, 2011a). (Figures 3 to 5)

The consistency of the development across the different parcels erected by eight house building firms using a wide variety of house types is due to the support of the local authority for the design code imposed by the landowner. It is ironic that the urban designer responsible for overseeing the code lost her job immediately after completion of the scheme as a result of public sector economies. This raises the issue of urban design 


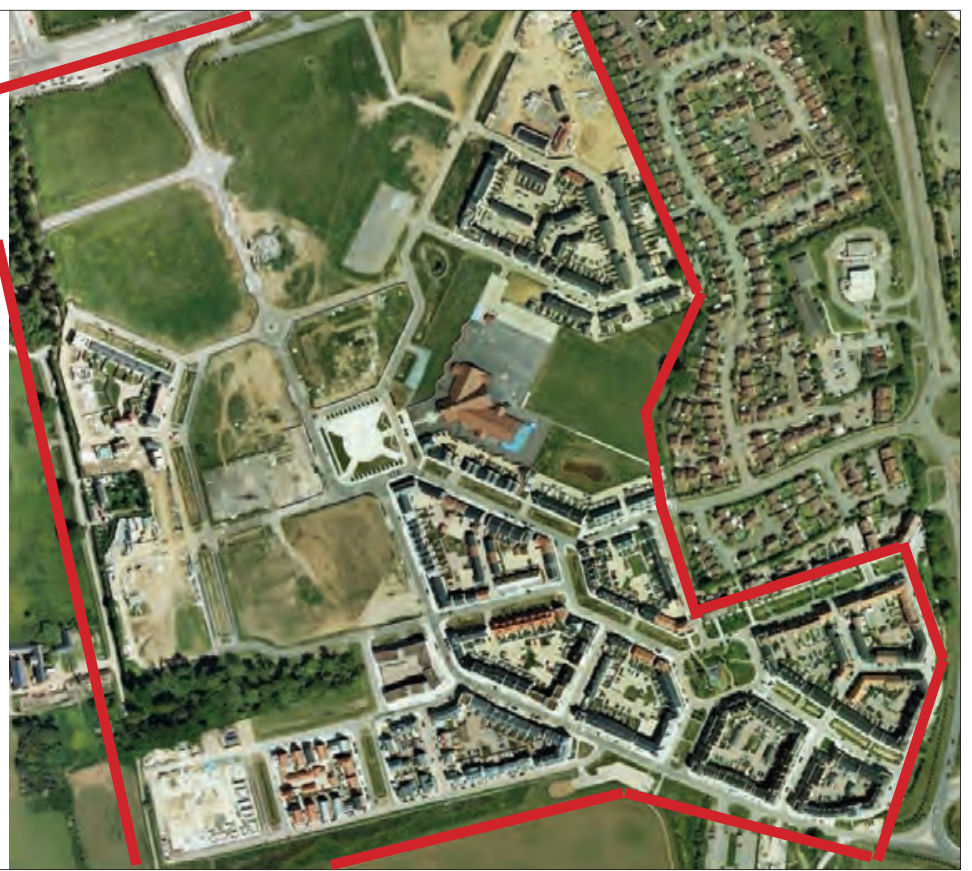

development, no plan existed. The code had to incorporate a degree of uncertainty as to future uses. Twenty-four sites had been identified for change. The Action Area plan gave a preferred range of uses for each site but no guidance on the form of development or its relation with the public realm. In the absence of a vision the Code had to provide clarity as to what would be considered acceptable design quality.

The author and Sue McGlynn, practising as Placemaking Associates, were commissioned to prepare the design code in 2006 and it was adopted in 2008 at the start of the biggest financial crash for a century. This of course affected the expectations for disposal of the sites-property investment slowed down dramatically and none of the expected change took place. However, the code is still being used as the property market recovers and a recent interview with officers of Oxford City Council Planning Department confirmed that, as interest was being revived, the code was proving a useful reference for discussion with potential developers (Oxford City Council, 2008).

OWEC was innovative in a number of ways. It set out to be easily understood by those who had to operate it with a step by step guide to its use. Because of the uncertainly over uses, it proposed a variable street mesh depending on future uses, i.e., a finer mesh for residential streets as opposed to a coarser one for larger buildings. It proposed that any larger buildings should be sleeved with smaller units to avoid the large blank facades which are often the result of free standing buildings. Unlike most residential codes, it tried to establish a minimum of criteria for the design of the buildings and the examples chosen to illustrate the principles laid down were exclusively local.

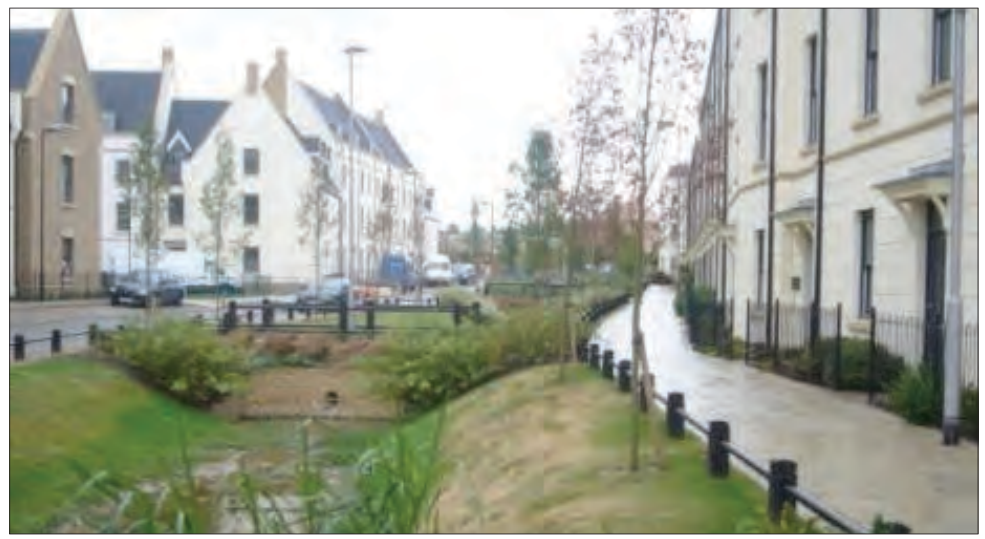

Figures 6 to 8: Aerial view of Upton with the completed first phase, the swale drainage system and the interior of a residential block. (photos Google Earth and the author)

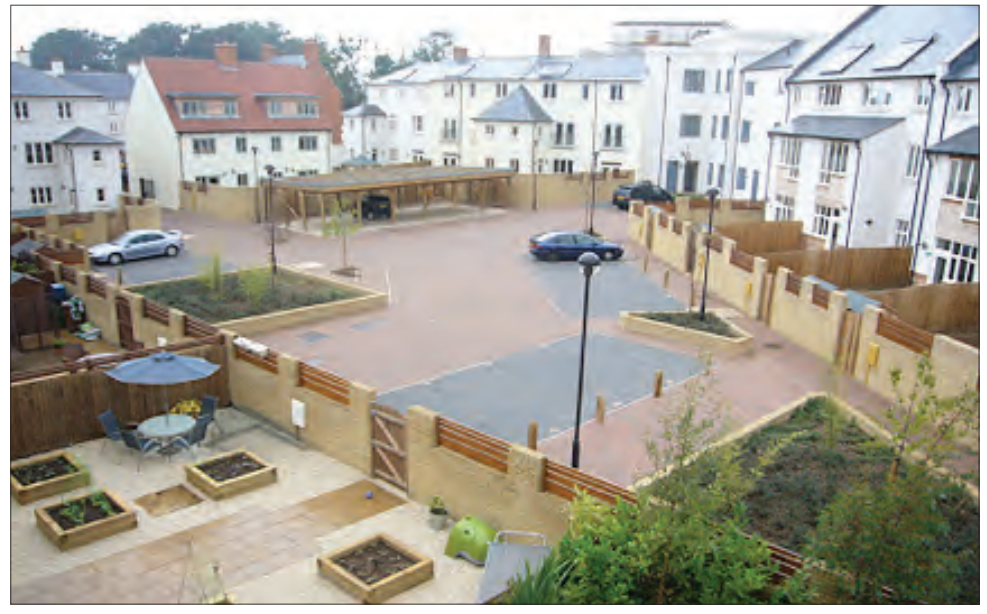

The code can be considered eclectic in that it draws on a number of approaches for its inspiration and often combines them in ways which may upset purists. For example, it uses a regulating plan drawn from New Urbanist practice and while ascribing to the principles of townscape it uses concepts drawn from Space Syntax to establish how and where variations from standard street design should occur (Figures 9 to 12).

In the words of the Government inspector who carried out an evaluation of the West End Action Plan:

"The West End Design Code is a comprehensive document based on a combination of general urban design principles and the place-specific qualities of Oxford City centre and the West End. Its priority is to set the relationships between building facades and the public realm, the form and mass of buildings in relation to one another, and the scale and types of streets and urban blocks. It has sought to identify the least number of most significant and long-lasting elements of the public realm of the West End in order to provide a flexible framework for the generation of a new, successful and highly locally distinctive public realm. I 
consider that this innovative Design Code, which has been commissioned specifically for the West End, will ensure that local features that make the area distinctive are considered and built upon in its renaissance." (Bussey, 2008, p. 12)

\section{Conclusions}

This section is based on a number of published studies (Street, 2007) and interviews with the planning officers charged with implementing codes both in Oxford, as noted above, and with as yet unpublished evaluations of design codes carried out by the author in France (Samuels, 1999). The most striking finding of these interviews was how difficult codes proved to be in use, especially if they have to be implemented by professionals who have not been associated with their production. This is not only the case where consultants have been contracted to produce the code but also where staff changes in local government have replaced officers who may have had a close involvement in the production of the instrument and therefore must be assumed to have been familiar with its operation.

Codes are regarded with some suspicion by architects in that they "represent a threat to designers' creative autonomy" (Street, 2007, p. 5). This in spite of the fact that some of our best loved places have been designed according to design codes and that architects concerned with buildings as unique objects are often unconcerned with the public realm that these buildings produce. The argument has also been raised that the detailed codes remove the need for an architect and therefore constitute a threat to their employment prospects.

Street's survey found that $22 \%$ of architects surveyed (the total number of responses to a postal survey was 207) agreed that codes were a good thing while 39\% disagreed. One anonymous respondent observed that "they were a reaction to the dreadful mess that we made... you know, with the normal private housing estates, the cul de sac crap that we produced right across the country that was simply allowing builders to do what they wanted" (Street, 2007, p. 11).

The point must be that architects are controlled by their clients and in the case of the major house builders this means repeating standard house types on the most economical layouts - so that the possibility of the architect being free to innovate in design is in most cases a myth. However, if codes result in avoiding the worst $25 \%$ of development perhaps missing the $5 \%$ of iconic projects is a price worth paying.

Those developments in England which have used design codes tend to appeal to the better off and younger purchasers. They have thus been accused of social exclusion in that they tend to be more expensive schemes. This claim is supported by some evidence at Upton where a two bedroom apartment costs more than the average home in the locality (Street, 2007, p. 33). The character of Fairfield Park as a virtual, if not literal, gated community has been pointed out and these types of development are distinguished by their social exclusivity.
It is also more difficult to impose a design code where the housing market is less buoyant. For example the Dorset market town where Poundbury has been developed is a wealthier area than South Manchester where a code was proposed for the district of Hulme.

It is claimed that the use of design codes reduce the time taken to achieve planning permissions for new developments. However, these assertions do not take into account the time and resources needed to prepare the design code in advance of the application.

In summary, it is suggested that any code must pass the PEST test. The code has to demonstrate four types of feasibility:

- Political - acceptable to the local authority;

- Economic - it must be capable of meeting the market context, if not it will not get built;

- Social - acceptable to both future inhabitants and existing neighbours;

- Technical - it must satisfy standards for highways, maintenance, and environmental impacts.

Furthermore, it is suggested that any code must obey five commandments. It must be:

- Precise, in its demands of developers

- Positive, in emphasisng what should be built rather than what should be avoided;

- Prescriptive, in giving stakeholders an argued justification for the content of the code;

- Prioritising its impacts on the public realm, which must be its main concern;

- Produced by design enquiry and stakeholder involvement.

The author hopes that this article and the lessons from these experiences may contribute to similar efforts in other contexts.

\section{References}

Briggs, G., \& Thomson, G. (2008). Design codes as a collaborative tool. Retrieved from http://www.rudi.net/ files/Placemaking_P34-36.pdf

Bussey, S. (2008). Report to Oxford City Council: Planning \& Compulsory Purchase Act 2004 section 20: Report on the examination into the Oxford West End Area Action Plan (File Reference No. LDF000598). Retrieved from Oxford City Council website: http://oxford.gov.uk/ Direct/74159Inspectorsreport.pdf

Carmona, M. and Dann, J. (2007). Design Codes. Urban Design, 101, 16-35. Retrieved from http://www.udg.org.uk/ publications/journal 
Commission for Architecture and the Built Environment. (2003). The use of urban design codes: Building sustainable communities. Retrieved from http://webarchive.nationalarchives.gov.uk/20110118095356/http:/www.cabe.org.uk/ files/the-use-of-urban-design-codes.pdf

Commission for Architecture and the Built Environment. (2005). Design coding: Testing its use in England. Retrieved from http://webarchive.nationalarchives.gov. uk/20110118095356/http://www.cabe.org.uk/files/designcoding.pdf

Commission for Architecture and the Built Environment. (2011a). Fairfield Park: Stotfold, Bedfordshire. Retrieved from http://webarchive.nationalarchives.gov. uk/20110118095356/http://www.cabe.org.uk/casestudies/fairfield-park

Commission for Architecture and the Built Environment. (2011b). Upton (phase 1, site A): Northhampton. Retrieved from http://webarchive.nationalarchives.gov. uk/20110118095356/http:/www.cabe.org.uk/case-studies/ upton-phase-one

Department for Communities and Local Government. (2006a). Design coding in practice: An evaluation. Retrieved from Public Health England website: http://www.apho.org.uk/ resource/item.aspx?RID $=92300$

Department for Communities and Local Government. (2006b). Preparing design codes: A practice manual. Retrieved from https://www.gov.uk/government/uploads/system/ uploads/attachment_data/file/7623/152675.pdf;

Duchy of Cornwall. (n.d.). Poundbury [Webpage]. Retrieved from http://duchyofcornwall.org/poundbury.html

EDAW. (2005). Upton Design Code, Northampton Borough Council. Retrieved from http://www.northampton.gov.uk/ info/200205/planning_for_the_future/1739/

Essex County Council. (1973). A design guide for residential areas. Chelmsford: Essex County Council.

Larkham, P. J. (2001). Regulation and the shaping of urban form in the UK (Working paper series, No. 83). Birmingham, England: School of Planning and Housing, The University of Central England.

Marshall S. (Ed.). (2011). Urban coding and planning. London, England: Routledge.

Oxford City Council. (2007). Oxford West End Design Code. Retrieved from http://oxford.gov.uk/PageRender/decP/ West_End_AAP_occw.htm

Oxford City Council. (2008). West End Area Action Plan. Retrieved from http://www.oxford.gov.uk/ Direct/76583Volume2.pdf

Samuels, I. (1999). A typomorphological approach to design: The plan for St Gervais. Urban Design International, 4 (3 \& 4), 129-141. doi:10.1080/135753199350045
Street, E. ( 2007). The use of design codes in England ; the codification and regulation of architects practices. Project Paper 5. Department of Geography, Kings College, University of London.

Talen, E. (2009). Design by the rules: The historical underpinnings of form-based codes. Journal of the American Planning Association 75(2), 144-160.

Tetlow King. (2002). Fairfield park urban design strategy. Biggleswade, Mid: Bedfordshire District Council. 